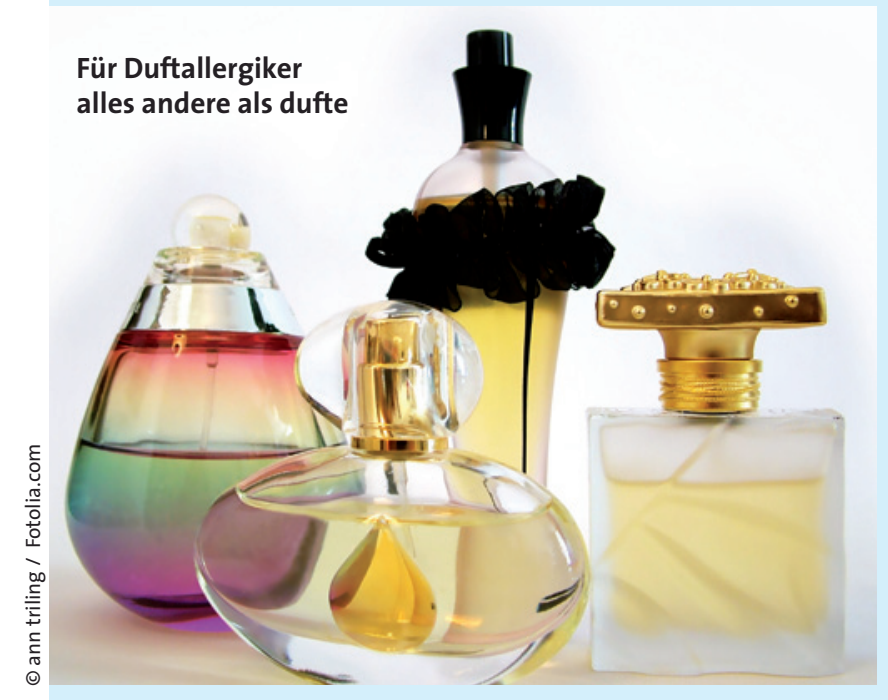

Außergewöhnlicher Rechtsstreit

\title{
Kein Honorar für duftende Therapeutin
}

— Ist ein Patient gegen Duftstoffe allergisch, darf er die Therapie abbrechen und das Honorar verweigern, wenn die Therapeutin nach Parfüm duftet. So entschied das Amtsgericht Rheinbach in einem außergewöhnlichen Rechtsstreit. Der Fall: Im Mai 2008 hatte eine Patientin eine Therapiesitzung bei ihrer Naturheilkunde-Therapeutin abgebrochen, weil die Therapeutin ein dezentes Parfüm aufgelegt hatte - obwohl die Patientin gegen Duftstoffe allergisch war und gegen eben diese Allergie behandelt werden sollte. Die Frau fürchtete eine allergische Reaktion wegen des Parfüms. Sie verließ die Praxis und weigerte sich später, die Therapiesitzung zu bezahlen.

So geht es nicht, fand die Therapeutin: Sie habe zwar ein Parfüm getragen, dessen Duft sei aber nicht intensiver gewesen als eine Pflege mit einem Deodorant. Das stelle keinen Grund dar, die Behandlung abzubrechen und das Honorar zu verweigern, so ihr Standpunkt. Dem widersprach das Amtsgericht Rheinbach in seinem Urteil vom 19. Juli 2010 (5 C 437/og).

Wer Duftallergiker behandle, müsse entsprechende Rücksichten nehmen. Solche Patienten dürften in der Praxis keinen Duftstoffen ausgesetzt werden. Wenn die Therapeutin selbst eine Duftquelle darstelle, verletze sie damit ihre vertragliche (Neben-)Pflicht, die Patientin zu schützen. Ob ihr Parfüm auffällig gewesen sei oder nicht, spiele dabei keine Rolle: Für einen Allergiker sei es nicht entscheidend, ob ein Parfüm intensiv rieche, denn die bloße Existenz von Duftstoffen könne ja eine allergische Reaktion hervorrufen. 